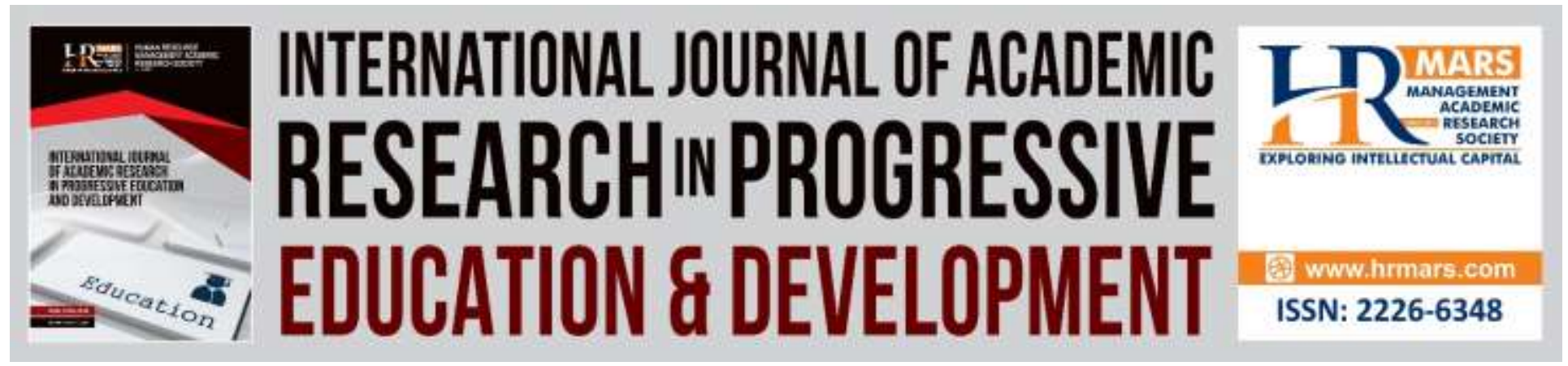

\title{
Systematic Literature Review on Secondary School Students' Mathematics Self-Efficacy
}

\author{
Nurul Ain Roslan, Siti Mistima Maat
}

To Link this Article: http://dx.doi.org/10.6007/IJARPED/v8-i4/6817

DOI:10.6007/IJARPED/v8-i4/6817

Received: 10 November 2019, Revised: 30 November 2019, Accepted: 11 December 2019

Published Online: 27 December 2019

In-Text Citation: (Roslan \& Maat, 2019)

To Cite this Article: Roslan, N. A., \& Maat, S. M. (2019). Systematic Literature Review on Secondary School Students' Mathematics Self-Efficacy. International Journal of Academic Research in Business and Social Sciences, 8(4), 975-987.

Copyright: (C) 2019 The Author(s)

Published by Human Resource Management Academic Research Society (www.hrmars.com)

This article is published under the Creative Commons Attribution (CC BY 4.0) license. Anyone may reproduce, distribute, translate and create derivative works of this article (for both commercial and non-commercial purposes), subject to full attribution to the original publication and authors. The full terms of this license may be seen at: http://creativecommons.org/licences/by/4.0/legalcode

Vol. 8(4) 2019, Pg. 975 - 987

http://hrmars.com/index.php/pages/detail/IJARPED

JOURNAL HOMEPAGE

Full Terms \& Conditions of access and use can be found at http://hrmars.com/index.php/pages/detail/publication-ethics 


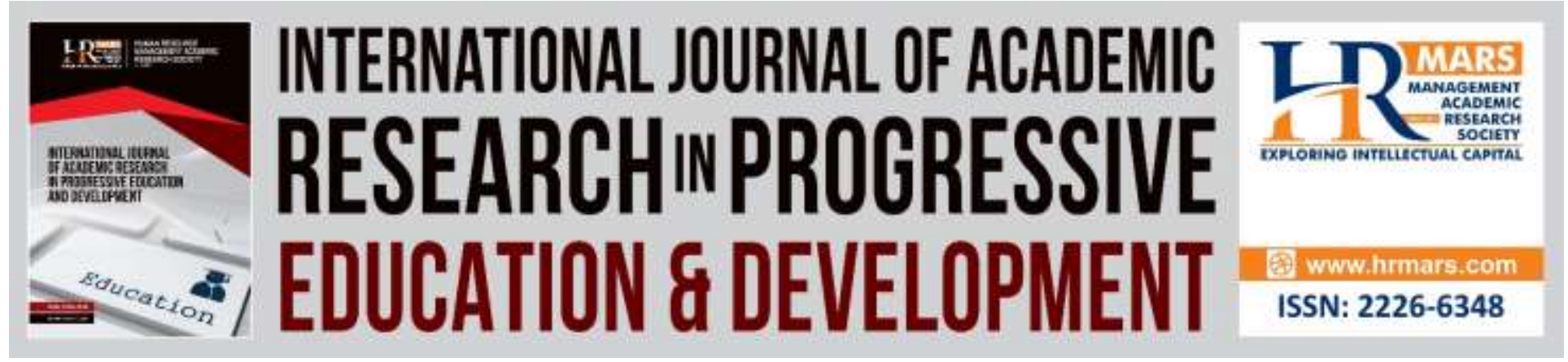

\title{
Systematic Literature Review on Secondary School Students' Mathematics Self-Efficacy
}

\author{
Nurul Ain Roslan, Siti Mistima Maat \\ Faculty of Education, Universiti Kebangsaan Malaysia \\ Email: P97611@siswa.ukm.edu.my \& sitimistima@ukm.edu.my
}

\begin{abstract}
Mathematics self-efficacy is one of the essential behavioural factors in mathematics learning for students. The aim of this review was to determine the relationship of secondary school students' mathematics self-efficacy and their performance in mathematics. Other than that, this review also studied the factors that can influence secondary school students' mathematics self-efficacy. The articles were collected from January 2015 until 2019 across one of the Google Scholar databases. A total of 26 studies were selected for this review. The inclusion and exclusion criteria were performed before starting the review. The results show that there was a positive relationship between secondary school students' mathematics self-efficacy and their performance in mathematics. The factors that influenced the secondary school students' mathematics self-efficacy were their mathematics anxiety, teacher support, online learning, program, learning materials, instructional games and discovery learning. Overall, this review shows that mathematics self-efficacy plays an important role in improving secondary school students' performance in mathematics.
\end{abstract}

Keywords: Mathematics Self-Efficacy, Secondary School, Students, Mathematics

\section{Introduction}

Mathematics is one of the most important subjects in this country's education system. However, mathematics is well known as the killer subject where students tend to have trouble getting good grade because students usually get bad grades in mathematics, they also think that mathematics is one of the most challenging subjects, which ultimately makes students less interested in mathematics. In addition, the performance of Malaysian secondary school students in science and mathematics subject are still below the targeted Key Performance Indicator (KPI) in the international stage. For example, in Trends in International Mathematics and Sciences Study (TIMSS), Malaysian students are still in the low level in the program. This was an unfavourable result showing that Malaysia is still lagging compared to neighbouring countries like Singapore. Furthermore, in the Programme for International Students Assessment (PISA), more that $50 \%$ of Malaysian students still failed to score the minimum marks required in 
mathematics. Malaysia was in ranked 57th out of 74 countries involved in PISA. This proves that the performance of Malaysian students in mathematics is still in the below the national target.

Many factors of deterioration and problems in learning mathematics have been identified by experts in the field of research. Student's attitude and students' interest can affect their achievement in mathematics (Abu \& Eu, 2014). According to Cikrikci \& Odaci (2016), metacognitive awareness and self-efficacy are factors that can affect students in their performance in mathematics. Self-efficacy has been known as the most social cognitive factors that can influence someone's achievement (Sheu et al., 2010). Based on Bandura's study (1994), self-efficacy is someone's belief of their ability and social skill when doing tasks. Someone who believe in their own ability are motivated to take an action and patient in difficulties (Bandura, 2006).

Self-efficacy is someone's confidence in his or her actions to generate or achieve something that he or she expects (Bandura, 1977). This theory explains the level of individual confidence in his ability to do certain assignment (Bandura, 1977). Self-efficacy describes how confident students are in doing their specific task (Perez \& Ye, 2013). Many studies have proven that self-efficacy can have a positive effect on a variety of things, including academic performance (Feldman \& Kubota, 2015; De Clercq, Galand, Dupont \& Frenay, 2013). There are many studies on self-efficacy based on the specific subject like reading self-efficacy, English selfefficacy, mathematics self-efficacy, STEM self-efficacy and others.

A student's confidence in dealing with and solving problems involving mathematics is referred to as mathematics self-efficacy. Mathematics self-efficacy can also play an important role in improving the student's academic performance and helping students to stay in science stream (Parker, March, Ciarrochi, Marshall \& Abduljabbar, 2014). Therefore, the aim of this study is to review several previous studies on the relationship of secondary school students on their mathematics self-efficacy and their performance in mathematics, and the factors that can influence the secondary school students' mathematics self-efficacy. This study is conducted to answer two research questions: a) What is the relationship of secondary school students' mathematics self-efficacy and their performance in mathematics; and b) What are the factors that can influence the secondary school students' mathematics self-efficacy?

\section{Background}

The definition of self-efficacy that has been proposed by Social Cognitive Theory is an expectation on own's attitudes and effort to do or experience some tasks or behaviours (Bandura, 1977). Cognitively, self-efficacy is someone's belief on their own ability and social skill when doing some work (Bandura, 1994). Bandura (1977) described self-efficacy as one's belief on their own ability to organize and take an action to achieve good results. The authors used this definition as a main guideline while reviewing all the articles selected.

The authors used the definition of mathematics self-efficacy from Hackett \& Betz (1989) and Pajares \& Miller (1995) in this review. The former defined mathematics self-efficacy as a condition or specific problem assessment of an individuals' confidence in their own ability to successfully perform or accomplish a specific mathematics assignment or problem. Therefore, as a guideline, the author defined secondary school students' mathematics self-efficacy as students' belief on their ability to do tasks or solve mathematical problems when reviewing all the articles 
Vol. 8, No. 4, 2019, E-ISSN: 2226-6348 @ 2019 HRMARS

related. Hence, high self-efficacy is required mainly to help students in their mathematics performance.

\section{Method}

According to Fink (2014), while doing a research on systematic literature review, the information is usually accessed online using bibliographic or article database and websites. In this study, the review was conducted using a bibliographic database which was Google Scholar. The articles were written between January 2015 and 2019. There were five steps by Khan et al. (2003), being used in this review. The steps were described in Figure 1.

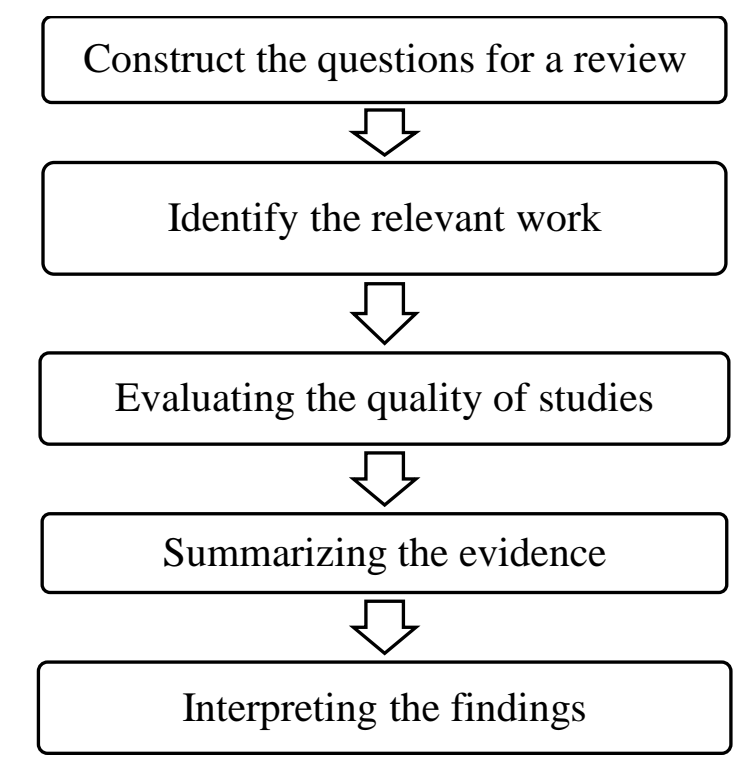

Figure 1 Stages of Systematic Literature Review

\section{Stage 1: Construct the Questions for a Review}

The literature review are research inquiries that should be guided by research questions. In this review, there are two research questions. The selected articles for this study are the articles that determined the relationship of secondary school students' mathematics self-efficacy and their performance in mathematics and the factors that can influence secondary school students' mathematics self-efficacy. Factors that can affect secondary school student's mathematic selfefficacy is defined as any multidimensional construct by Bandura (1977). Some of the factors are mastery experiences, vicarious experiences, oral praise and emotional arousal.

\section{Stage 2: Identify the Relevant Work}

The search for this review was performed in two phases: a) conducted using online databases which is Google Scholar and collecting all related articles based on initial search; and b) choosing articles from the initial search based on inclusion and exclusion criteria in this review. The articles were limited in the range of 5 years which is between January 2015 until 2019. The following keywords were employed in this search: "mathematics self-efficacy" AND "secondary school students"; "mathematics self-efficacy" AND "middle school students"; "mathematics self- 
efficacy" AND "high school students" and "mathematics self-efficacy". The limiter was applied while searching for the articles based on the initial search so that only the relevant articles would be identified. The limiter for this review is English, peer review and full-text articles.

\section{Stage 3: Evaluating the Quality of Studies}

Inclusion and exclusion criteria are fixed in order to maintain the quality of this review. After the initial selection of the articles, the inclusion criteria were applied to determine studies that would be included in this review. Inclusion criteria for this review were limited to studies that (a) English peer-reviewed journal articles and conference papers; (b) published between 2015 and 2019 only; (c) available in full-text; and (d) the participants were secondary school students including middle school students and high school students. For the exclusion criteria, studies were excluded if they were dissertations, chapters, action research and review research.

Firstly, if the studies are in line with the two research questions, which was: a) What is the relationship of secondary school students' mathematics self-efficacy and their performance in mathematics? and b) What are the factors that can influence secondary school students' mathematics self-efficacy?; it would be included in this review. Next, studies that are related to the relationship between secondary school students' mathematics self-efficacy and factors that can affect the students' mathematics self-efficacy were included in this review. Researches that are not related to the theme framework were excluded.

Secondly, both quantitative and qualitative studies were included in this review as long as they used secondary school students including middle school and high school students as their samples or respondents. Samples or respondents other than mentioned were excluded. Lastly, the most important part is the discussion of the results of the studies must be explicit and in line with prior questions because the author needed to analyse the findings.

\section{Stage 4: Summarizing the Evidence}

This study aims to collect any researches that determined the relationship of students' mathematics self-efficacy and their performance in mathematics and the factors that can influence students' mathematics self-efficacy. In the first step of searching articles, there were 119 articles to be screened for the inclusion criteria which are English peer-reviewed and full text articles. 44 duplicate studies that had been found were removed. Next, the remaining articles were screened with other inclusion and exclusion criteria. Such articles used primary school students, university or college level students as their respondents and are not available in fulltext. Then, the dissertations, chapters, review paper, books were excluded from this review. Out of 119 articles found in the initial step, only 26 articles were confirmed to be used in this review. The summarize details of the searching process is shown in PRISMA diagram as shown in Figure 2. 


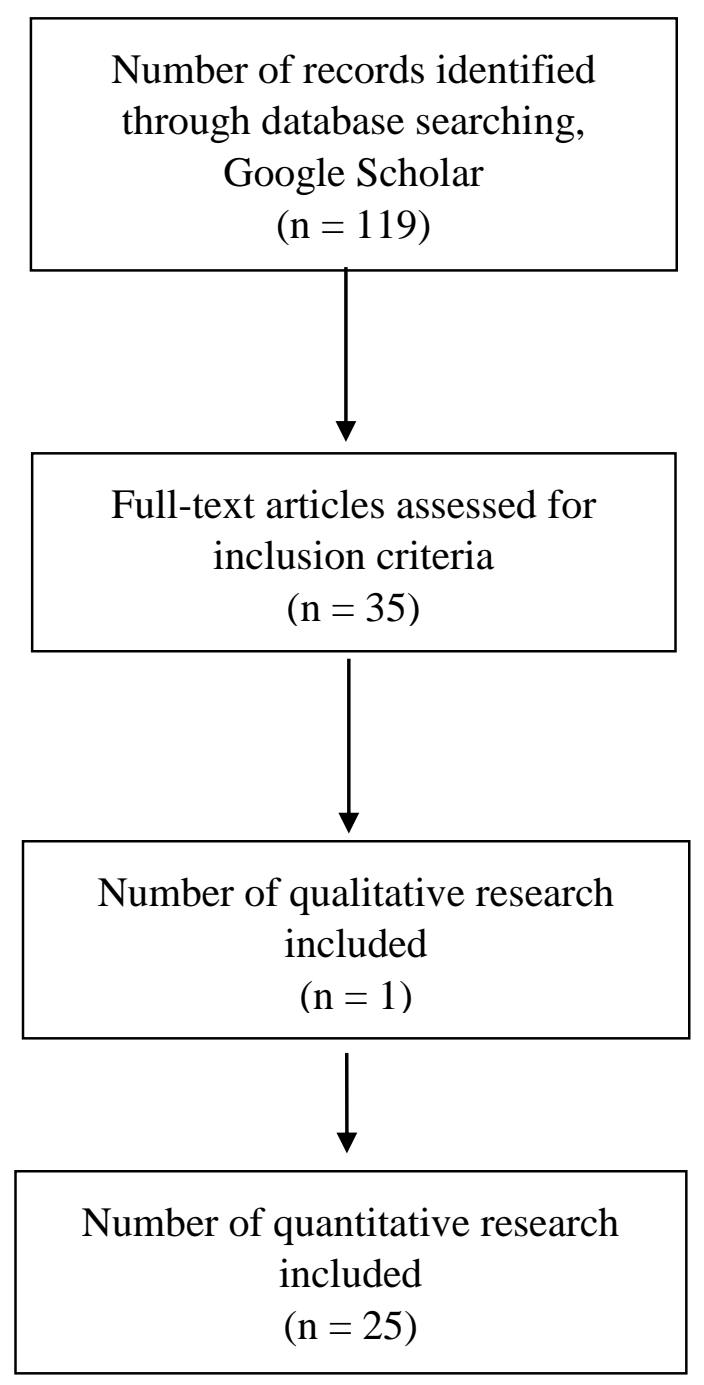

Figure 2 PRISMA Flows Diagram

\section{Stage 5: Interpreting the Findings}

Based on the research questions in this review, all the 26 articles were grouped into two. The articles were grouped based on the research questions that had stated by the author. Most of the studies reviewed were quantitative research. There are 25 quantitative studies and only 1 qualitative study. 5 out of 26 articles studied the relationship of secondary school students' mathematics self-efficacy and their performance in mathematics and 14 out of 26 articles investigated factors that can influence the secondary school students' mathematics self-efficacy. However, 7 out of 26 articles investigated both aspects. Thus, the next part of this review will analyse the articles and group it based on the research questions and the methodology of the study. Research question 1 refers to the relationship of secondary school students' mathematics self-efficacy and their performance in mathematics and research question 2 refers to the factors 
INTERNATIONAL JOURNAL OF ACADEMIC RESEARCH IN PROGRESSIVE EDUCATION AND

DEVELOPMENT

Vol. 8, No. 4, 2019, E-ISSN: 2226-6348 @ 2019 HRMARS

that can influence students' mathematics self-efficacy. Table 1 shows the analyses of the articles based on the review research questions.

\begin{tabular}{lccc}
\hline \multicolumn{1}{c}{ Methods } & $\begin{array}{c}\text { Research Question } \\
\mathbf{1}\end{array}$ & $\begin{array}{c}\text { Research Question } \\
\mathbf{2}\end{array}$ & $\begin{array}{c}\text { Both Research } \\
\text { Questions }\end{array}$ \\
\hline Quantitative study & 5 & 13 & 7 \\
Qualitative study & 0 & 1 & 0 \\
\hline
\end{tabular}

Table 1: Number of Study Based on Research Questions and Methods

The participants or samples of all the reviewed articles were secondary school students either middle school students or high school students. The sampling technique used by the researchers of the studies were mostly random sampling aimed at secondary school students. Most of the studies also conducted in the secondary school but there some studies were conducted in school holiday programs.

\section{Results}

The relationship of secondary school students' mathematics self-efficacy and their performance in mathematics.

These are the findings of past studies relating to the relationship of secondary school students' mathematics self-efficacy and their performance in mathematics in this section. The studies involved in this part are all the quantitative research. The complete list of the studies is shown in Table 2.

\begin{tabular}{l|l}
\hline Method & Author (Year) \\
\hline Quantitative study, $\mathbf{n = 5}$ & Kaya \& Bozdag (2016) \\
& Kesan \& Kaya (2018) \\
& Mundia \& Metussin (2018) \\
& Schober, Schutter, Koller, McElvany \& Gebauer (2018) \\
& Mumcu \& Aktaş (2015) \\
\hline
\end{tabular}

Table 2: List of Reviewed Studies of Relationship of Secondary School Students' Mathematics self-efficacy and Their Performance in Mathematics

Overall, it showed that to investigate a relationship of the secondary school students' mathematics self-efficacy and their performance in mathematics, most of the research used quantitative method. Overall, most of the studies regarding the relationship of the secondary school students' mathematics self-efficacy and their mathematics performance showed the positive results. All findings of the studies showed that the lower the secondary school students' mathematics self-efficacy, the lower the marks (performance) of mathematics results they scored. Usually, the studies showed that students' mathematics self-efficacy with some other factors such as mathematics anxiety (Aksu, Ozkaya, Gedik \& Konyalıoglu, 2016; O’Keeffe, White, 
Vol. 8, No. 4, 2019, E-ISSN: 2226-6348 @ 2019 HRMARS

Panizzon, Elliott, \& Semmens, 2018; Reyes, 2019a; Reyes, 2019b; Recber, Isikal \& Koc, 2018; Yuksel \& Geban, 2016), teacher support (Wu, 2016; Yildirim \& Yildirim, 2019), online learning (Ichinose \& Bonsangue, 2016; Parsons \& Gonzalez, 2018), program (Cleary, Velardi \& Schnaidman, 2017; Snipes, Huang, Jaquet \& Finkelstein, 2016), learning materials (Cai, Liu, Yang \& Liang, 2019; Peranginangin, Saragih \& Siagian, 2019; Ulandari, Amry \& Saragih 2019), instructional games (Reyes, 2019b), and discovery learning (Simamora, Saragih \& Siregar, 2019) influenced the secondary school students' performance in mathematics. Hence, the students that have high performance in mathematics were the students' that have high mathematics selfefficacy and vice versa.

\section{The Factors that can Influence Secondary School Students' Mathematics Self-Efficacy}

This section explains the findings of past researches relating to the factors that can influence to the secondary school students' mathematics self-efficacy. There are 7 studies that investigated both relationship and factors and 14 studies investigated the factors that affect the secondary school student' mathematics self-efficacy. There is only 1 qualitative study by Reyes (2019) that explored the effects of students' mathematics anxiety towards mathematics self-efficacy. The complete list of studies that determined both; the relationship of secondary school students' mathematics self-efficacy and factors affecting their mathematics self-efficacy is as shown in Table 3.

\begin{tabular}{l|l}
\hline Method & Author (Year) \\
\hline Quantitative study, $\mathbf{n = 2 0}$ & Azku et al. (2015) \\
& Cai et al. (2019) \\
& Cleary et al. (2017) \\
& Escalera-Chavez, Rojas-Kramer \& Garcia-Santillan (2018) \\
& Ichinose \& Bonsangue (2016) \\
& Kalaycioglu (2015) \\
& O'Keeffe et al. (2018) \\
& Koyuncu \& Donmez (2018) \\
& Mokhtari \& Saadatmand (2016) \\
& Parson \& Ganzalez (2018) \\
& Peranginangin et al. (2019) \\
& Reyes (2019b) \\
& Recber et al. (2018) \\
& Saligumba \& Tan (2018) \\
& Simamora \& Saragih (2019) \\
& Snipes et al. (2016) \\
& Ulandari et al. (2019) \\
& Wu (2016) \\
& Yildirim \& Yildirim (2019) \\
& Yuksel \& Geban (2016) \\
& Reyes (2019a) \\
\hline
\end{tabular}


Vol. 8, No. 4, 2019, E-ISSN: 2226-6348 @ 2019 HRMARS

Table 3 List of Review Studies of Relationship of Secondary School Students' Mathematics SelfEfficacy and Factors that Affect Their Mathematics Self-Efficacy and Their performance in Mathematics

There are four self-efficacy multidimensional construct by Bandura (1977), which composed of mastery experiences, vicarious experiences, oral praise and emotional arousal. Most of the studies focus on giving the students mastery experiences. Most of the factors that can influence the secondary students' mathematics self-efficacy are an increase on their mastery experiences by giving online learning, program, learning materials, instructional games, discovery learning and other related activities. The programs or activities are mostly conducted in the school and some during the summer school holiday. Most of the studies have pre-test and posttest conducted to examine the relationship of the activities and mathematics self-efficacy. There was only 1 activity by Saligumba \& Tan (2018) that showed no difference between students that were exposed to the model and students that were not exposed to the model. Hence, the level of mathematics anxiety of the students would decrease as their mathematics self-efficacy increase by giving them mastery experiences. Decreasing the students' mathematics self-efficacy is also a factor that can affect the mathematics self-efficacy. There was an inverse correlation between student' mathematics self-efficacy and their mathematics anxiety (O'Keeffe et al., 2018; Parson \& Ganzalez, 2018; Recber et al., 2018; Azku et al., 2015; Yuksel \& Geban, 2016).

Next, the support from the teachers can also influence the secondary school students' mathematics self-efficacy. The support from the teachers can be included in verbal praise. There are only 2 out of 26 studies that investigated the influence of teacher support as the factor affecting the secondary school students' mathematics self-efficacy. The two studies were conducted by Wu (2016) and Yildrim \& Yildrim (2019). There is a positive correlation between the teacher support and secondary school students' mathematics self-efficacy. Hence, it shows that all the factors that affect the secondary school students' mathematics self-efficacy are mostly related to social cognitive theory.

\section{Discussion}

The discussion provided is based on methodological and theoretical issues. In the methodological issue, the issues can be viewed based on the method used in the study. 25 out of 26 studies used quantitative method and only 1 out of 26 studies used qualitative method. Because of this, it can be concluded that most of the studies conducted used quantitative method. This is because the aim of the studies is to identify the factors influencing the relationship between mathematics self-efficacy and performance in mathematics. While exploring the relationship between variables, quantitative method was the most preferable method by social science researchers (Creswell, 2009). The research instruments used were mostly questionnaire. The questionnaire for mathematics self-efficacy used by the studies were mostly adapted from other researchers like May (2009), Umay (2001) and Usher \& Pajares (2008).

In theoretical issues, most of the studies were discussions on Social Cognitive Theory by Bandura. Most of the studies observed the theory based on the students' self-efficacy and combined them with mathematics self-efficacy. The studies were (Azku et al., 2015; Cai et al., 2019; Inchinose \& Bonsangue, 2016; Kalaycioglu, 2015; Kesan \& Kaya, 2018; Recber et al., 2018; Reyes, 2019a; Reyes, 2019b; Simamora \& Saragih, 2019; Schober et al., 2018; Ulandari et al., 
2019; Mumcu \& Aktaz, 2015; Yuksel \& Geban, 2016). The studies show that the lower the secondary school students' mathematics self-efficacy, the lower their self-confidence doing mathematics tasks or tests.

Based on the results, the factors that can influence the secondary school students' mathematics self-efficacy were students' mathematics anxiety, teacher support, online learning, program, learning materials, instructional games and discovery learning. Hence, the secondary school students with higher level mathematics self-efficacy tend to have high performance in mathematics.

\section{Conclusion and Future Research}

The issues investigated in this review are related to the relationship of secondary school students' mathematics self-efficacy and their performance in mathematics and the factors that can influence the secondary school students' mathematics self-efficacy. Based on the aim, results and discussion of this review, the conclusion that can be drawn is there is a positive correlation between secondary school students' mathematics self-efficacy and their performance in mathematics. This shows that, self-efficacy is one of the factors that can help students to have better performance in mathematics. Next, the factors that can influence the secondary school students' mathematics self-efficacy are their mathematics anxiety, teacher support, online learning, program, learning materials, instructional games and discovery learning. This shows that teachers need to help students in many ways to improve their mathematics self-efficacy, so that their performance in mathematics can be increased.

Hence, from all the studies that were reviewed, they were mostly focused on mastery experiences than other sources like vicarious experiences, oral persuasions and emotional arousal which have been stated by Bandura (1977). Therefore, it is suggested that future research attempt to cover and explore other sources (vicarious experiences, oral persuasions and emotional arousal) to increase the secondary school students' mathematics self-efficacy. Next, it is recommended for future studies to review on factors that can affect self-efficacy on other subjects like English, science, history and others. Lastly, the participants of the research may be primary school students, college students and others.

\section{Acknowledgement}

This work was supported by the Universiti Kebangsaan Malaysia grant GG-2019-065 and PPFPEND-2019.

\section{References}

Abu, N. E. B., \& Eu, L. K. (2017). Hubungan antara sikap, minat, pengajaran guru dan pengaruh rakan sebaya terhadap pencapaian matematik tambahan tingkatan 4. JuKu: Jurnal Kurikulum \& Pengajaran Asia Pasifik, 2(1), 1-10.

Aksu, Z., Ozkaya, M., Gedik, S. D., \& Konyalıoglu, A. C. (2016). Mathematics self-efficacy and mistake-handling learning as predictors of mathematics anxiety. Journal of Education and Training Studies, 4(8), 65-71.

Bandura, A. (1977). Self-efficacy: toward a unifying theory of behavioral change. Psychological review, 84(2), 191. 
Bandura, A. (1994). Self-Efficacy. Encyclopedia of Human Behavior, 4, 71-81.

Bandura, A. (2006). Guide for constructing self-efficacy scales. Self-efficacy beliefs of adolescents, 5(1), 307-337.

Cai, S., Liu, E., Yang, Y., \& Liang, J. C. (2019). Tablet-based AR technology: Impacts on students' conceptions and approaches to learning mathematics according to their selfefficacy. British Journal of Educational Technology, 50(1), 248-263.

Cikrikci, Ö., \& Odaci, H. (2016). The determinants of life satisfaction among adolescents: The role of metacognitive awareness and self-efficacy. Social Indicators Research, 125(3), 977-990.

Cleary, T. J., Velardi, B., \& Schnaidman, B. (2017). Effects of the Self-Regulation Empowerment Program (SREP) on middle school students' strategic skills, selfefficacy, and mathematics achievement. Journal of School Psychology, 64, 28-42.

Creswell, J. W. (2009). Research Design: Qualitative, Quantitative and Mixed Approaches (3rd. Ed.). United States of America: Sage Publications.

De Clercq, M., Galand, B., Dupont, S., \& Frenay, M. (2013). Achievement among first-year university students: an integrated and contextualised approach.European Journal of Psychology of Education, 28, 641-662.

Escalera-Chávez, M. E., Rojas-Kramer, C. A., \& García-Santillán, A. (2018). Self-efficacy in highschool students. Journal of Psychological and Educational Research, 26(1), 40- 50.

Feldman, D. B., \& Kubota, M. (2015). Hope, self-efficacy, optimism, and academic achievement: Distinguishing constructs and levels of specificity in predicting college grade-point average. Learning and Individual Differences, 37, 210-216.

Fink, A. (2014). Conducting research literature reviews: from the Internet to paper. Sage Publications.

Hackett, G., \& Betz, N. E. (1989). An exploration of the mathematics self-efficacy/mathematics performance correspondence. Journal for Research in Mathematics Education, 20, 261273.

Ichinose, C., \& Bonsangue, M. (2016). Mathematics Self-Related Beliefs and Online Learning. Learning Assistance Review, 21(1), 55-70.

Kalaycioglu, D. B. (2015). The Influence of Socioeconomic Status, Self-Efficacy, and Anxiety on Mathematics Achievement in England, Greece, Hong Kong, the Netherlands, Turkey, and the USA. Educational Sciences: Theory and Practice, 15(5), 1391-1401.

Kaya, D., \& Bozdag, H. C. (2016). Resources of Mathematics Self-Efficacy and Perception of Science Self-Efficacy as Predictors of Academic Achievement. European Journal of Contemporary Education, 18(4), 438-451.

Keşan, C., \& Kaya, D. (2018). Mathematics and Science Self-Efficacy Resources as the Predictor of Academic Success, International Online Journal of Educational Sciences, 10(2), 45-58.

Khan, K. S., Kunz, R., Kleijnen, J., \& Antes, G. (2003). Five steps to conducting a systematic review. Journal of the royal society of medicine, 96(3), 118-121.

Koyuncu, B., \& Dönmez, P. (2018). Predictive Value of Sense of Self-Efficacy and Attitudes of High School Students for Their Resistance to Mathematics. Universal Journal of Educational Research, 6(8), 1629-1636. 
May, D.K. (2009). Mathematıcs self-effıcacy and anxiety questıonnaıre. Unpublished Doctoral Thesis, Graduate Faculty of The University of Georgia, Athens, Georgia.

Mumcu, H. Y., \& Aktaş, M. C. (2015). Multi-program high school students' attitudes and selfefficacy perceptions toward mathematics. Eurasian Journal of Educational Research, 15(59), 207-226.

Mundia, L., \& Metussin, H. (2019). Exploring factors that improve mathematics achievement in Brunei. Studies in Educational Evaluation, 60, 214-222.

Mokhtari, V., \& Saadatmand Z. (2016). Determining the effect of the implementation of problemsolving teaching on self-efficacy and learning mathematics in male students of the High School (grade seven) Najaf Abad City. International Journal of Humanities and Cultural Studies (IJHCS) ISSN 2356-5926, 1(1).

O'Keeffe, L., White, B., Panizzon, D., Elliott, K., \& Semmens, A. (2018). Mathematics Anxiety: Year 7 and 8 Student Perceptions. Mathematics Education Research Group of Australasia.

Pajares, F., \& Miller, M. D. (1995). Mathematics self-efficacy and mathematics performances: The need for specificity of assessment. Journal of counseling psychology, 42(2), 190.

Parker, P. D., Marsh, H. W., Ciarrochi, J., Marshall, S., \& Abduljabbar, A. S. (2014). Juxtaposing math self-efficacy and self-concept as predictors of long-term achievement outcomes. Educational Psychology, 34(1), 29-48.

Parsons, B. S., \& Gonzalez, O. R. G. (2018). A comparative study of mathematics self-efficacy and anxiety levels of Grades 10-12 students at Thai Christian School before and after supplemental practice use of the mathematics e-learning application website Khan Academy. Scholar: Human Sciences, 10(2), 207.

Peranginangin, S. A., Saragih, S., \& Siagian, P. (2019). Development of Learning Materials through PBL with Karo Culture Context to Improve Students' Problem Solving Ability and Self-Efficacy. International Electronic Journal of Mathematics Education, 14(2), 265-274.

Recber, S., Isiksal, M., \& Koç, Y. (2018). Investigating self-efficacy, anxiety, attitudes and mathematics achievement regarding gender and school type. Anales De Psicología/Annals of Psychology, 34(1), 41-51.

Reyes, J. D. C. (2019a). Mathematics Anxiety and Self-Efficacy: A Phenomenological Dimension. Journal of Humanities and Education Development (JHED), 1(1), 22-34.

Reyes, J. D. C. (2019b). Increasing Self-efficacy and Alleviating Anxiety using Touch Math and Instructional Games: An Intervention for Low Performing Seventh Graders. Journal of Humanities and Education Development (JHED), 1(2), 59-74.

Saligumba, I. P. B., \& Tan, D. A. (2018). Gradual Release of Responsibility Instructional Model: Its Effects on Students Mathematics Performance and Self-Efficacy. International Journal of Scientific \& Technology Research, 7(3), 276-291.

Schöber, C., Schütte, K., Köller, O., McElvany, N., \& Gebauer, M. M. (2018). Reciprocal effects between self-efficacy and achievement in mathematics and reading. Learning and Individual Differences, 63, 1-11. 
Sheu, H. B., Lent, R. W., Brown, S. D., Miller, M. J., Hennessy, K. D., \& Duffy, R. D. (2010). Testing the choice model of social cognitive career theory across Holland themes: A meta-analytic path analysis. Journal of Vocational Behavior, 76, 252-264.

Simamora, R. E., \& Saragih, S. (2018). Improving Students' Mathematical Problem-Solving Ability and Self-Efficacy through Guided Discovery Learning in Local Culture Context. International Electronic Journal of Mathematics Education, 14(1), 61-72.

Snipes, J., Huang, C. W., Jaquet, K., \& Finkelstein, N. (2016). The Effects of the Elevate Math Summer Program on Math Achievement and Algebra Readiness. Society for Research on Educational Effectiveness.

Ulandari, L., Amry, Z., \& Saragih, S. (2019). Development of Learning Materials Based on Realistic Mathematics Education Approach to Improve Students' Mathematical Problem-Solving Ability and Self-Efficacy. International Electronic Journal of Mathematics Education, 14(2), 375-383.

Umay, A. (2001). Effect of primary school mathematics teacher's program on mathematics selfefficacy. Journal of Qafqaz University, 8(1), 1-8.

Usher, E. L., \& Pajares, F. (2008). Sources of self-efficacy in school: critical review of the literature and future directions. Review of Educational Research, 78(4), 751-796.

Wu, Y. (2016). Universal Beliefs and Specific Practices: Students' Math Self-Efficacy and Related Factors in the United States and China. International Education Studies, 9(12), 61-74.

Yıldırım, S., \& Yıldırım, H. H. (2019). Predicting mathematics achievement: The role of perceived feedback, teacher support and self-beliefs. Turkish Journal of Education, 8(2), 71-85.

Yüksel, M., \& Geban, Ö. (2015). Examination of science and math course achievements of vocational high school students in the scope of self-efficacy and anxiety. Journal of Education and Training Studies, 4(1), 88-100. 